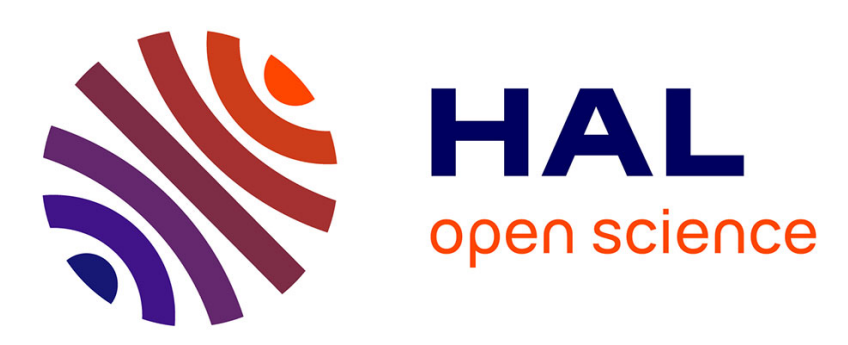

\title{
Sade, "sexual perversion" and us: another history of sexuality from the end of the Enlightenment to the 21st century
}

\author{
Julie Mazaleigue-Labaste
}

\section{- To cite this version:}

Julie Mazaleigue-Labaste. Sade, "sexual perversion" and us: another history of sexuality from the end of the Enlightenment to the 21st century. INSEP - Journal of the International Network for Sexual Ethics \& Politics, 2016, 4 (1), pp.27-37. halshs-01989406

\section{HAL Id: halshs-01989406 \\ https://shs.hal.science/halshs-01989406}

Submitted on 22 Jan 2019

HAL is a multi-disciplinary open access archive for the deposit and dissemination of scientific research documents, whether they are published or not. The documents may come from teaching and research institutions in France or abroad, or from public or private research centers.
L'archive ouverte pluridisciplinaire HAL, est destinée au dépôt et à la diffusion de documents scientifiques de niveau recherche, publiés ou non, émanant des établissements d'enseignement et de recherche français ou étrangers, des laboratoires publics ou privés. 
Sade, "sexual perversion" and us: another history of sexuality from the end of the Enlightenment to the 21st century

Pre-print of Mazaleigue-Labaste 2016. Sade, "sexual perversion" and us: another history of sexuality from the end of the Enlightenment to the 21st century, INSEP, Vol. 4, Issue 1-2016, pp. $27-37$

From the first psychiatrisation of "abnormal" sexualities in the middle of the $19^{\text {th }}$ century (i.e. the invention of the category of "sexual perversion") till today, the figure and the literature of Donatien Alphonse François de Sade have played a significant role in the discourses of medical, psychological and human sciences about sexuality. The purpose of this essay is to explore the functions and the importance of Sade for these scientific discourses, through the transformations of what one can call "the sadian legend" from the collective imaginary in the last decades of the 18th century to the full integration of Sade in the sexological knowledge during the first decades of the 20th century. I will support a strong thesis: the representation and the work of Sade were essential for the emergence of sexual psychology in the western world. This analysis will thereby contribute to develop a new view on the history of sexuality, of sexology and more broadly of what Michel Foucault (1976) named the Scientia Sexualis since the French Revolution. Providing this new view requires to question and critic two commonly accepted theses.

The first thesis concerns the way of thinking and creation of the history of sexuality. Since the 1970s, the history of "abnormal" sexuality in medicine and sexology has strongly questioned the normalization of sexual practices and identities by psychiatry, psychology and medicine (or "psy-function") (Foucault, 1976). These historical inquiries have concluded the main objective of these sciences was to reform same-sex relationships and gendernonconforming people by heavily promoting heterosexuality and the gender binary. Two reasons explain this focalisation on sexual and gender identities. The first is contextual. Critical views on medicalisation and psychiatrisation of sexuality have emerged in the 1960s and became a research field in the 1970s, in the context of sexual liberation and political fights for emancipation, especially feminist and gay and lesbian ones. The main issue was therefore gender and sexual orientation. The second reason is historiographical. These critical views have emphasised a specific moment in the history of sexuality : the importance 
acquired by homosexuality from the 1860s onwards in the Austrian-Hungarian Empire and Germany. Indeed, the same-sex relations (between men in Germany, but also between women in Austria) were strongly repressed by the law - the sadly notorious $\S 175$ of the German Penal Code of 1871 being exemplar. This repression was the origin of a law reform movement, which began in the 1860s with the jurist and essayist Karl Heinrich Ulrichs and increased during the next three decades. Renown psychiatrist and sexologists, as Richard von KrafftEbing, Albert Moll, Magnus Hirschfeld, took part in the fight against the $§ 175$. From Ulrichs to Hirschfeld, new theories about homosexuality demonstrated same-sex relations were neither criminal nor vicious but depended on a specific psychosexual organisation. And because psychiatrists and sexologists also studied sadism, masochism, fetishism, researchers have induced that the history of "sexual perversion" began during the 1860s in the Germanic area, and that homosexuality was the reference model for the other perversions. But actually, this history began in France during the first part of the century. Then, if the historical researches focusing on sexual and gender identities have been essential, they have nonetheless led to obfuscate another historical factor which is also crucial for the late modern and contemporary history of representations and experiences of sexuality in the western world: sadism and its intrinsic link to the work, figure and cultural place of Sade. Indeed, I will show the category of "sadism" and more widely the psychologisation of sexual violence is more significant for the early history of Scientia Sexualis than the psychiatrisation of homosexualities.

The second thesis to be challenged concerns Sade directly, and can be criticized by the analysis of philosophical principles expressed in Sade's work. This thesis is based on a representation constructed in the 20th century, but its origins are found in the psychopathology of sexuality and the first sexology in the 19th century. Maurice Heine, one of the great French editors of Sade between the 1920s and 1950, has very clearly expressed this thesis in 1936. In the first edition of his Collection of Psycho-sexual Confessions and Observations from Literature (Heine, 2013), Heine considered literature in a psychosexual and clinical perspective. He concluded D.A.F. de Sade was a very important sexological theorist and observer long before Richard von Krafft-Ebing (author of Psychopathia Sexualis, firstly edited in 1886) and Sigmund Freud, the evidence used to support this assertion being The 120 days of Sodom (Sade, 1998). Heine's reading of Sade makes him a precursor of the psychopathology of sexuality and therefore of sexology. But Heine's view about Sade is actually a mistake based on a misreading of Sade's writings (Mazaleigue-Labaste, 2014, p.5253), which appears in the comparison between the epistemological principle guiding the 
psychopathology of sexuality and the principle underlying Sade's description of strange and often horrific eroticisms.

The 19th century Scientia Sexualis described the multiple qualitative deviations of sexual instinct that the word "perversion" named stricto sensu in the technical vocabulary of medicine (Davidson, 2001; Mazaleigue-Labaste, 2014). But the literature of Sade follows a more quantitative scheme. One can even find this scheme in The 120 days of Sodom, which is often considered as the exemplary "sexological" text from Sade (1998). The 120 days of Sodom shows the maximum diversification of erotic qualities and singularities (from the smallest voyeurism to the worst atrocious crimes), and thus seems to develop a protodifferential clinic of abnormal sexuality. But it actually obeys to a quantitative epistemology not of sex but of crime, as it appears when we put it in the context of the global philosophical framework of Sade's thinking and writing.

Indeed, The 120 days of Sodom is guided by a principle of gradation (one day, one narrative, increasingly more cruel than the day before), which corresponds to the aggravation of the criminal practices of the debauchees (all new narrative must be put into practice, according to the principle enacted by Blangis) (Mazaleigue-Labaste, 2014, p.53). Because for Sade the main question is that of Crime, considered as a cardinal ethical value. Crime is the practical key of an ethics leading the accomplished libertine to release himself from all the contingencies expressed in the laws and social norms of the human world, this artificial second nature (Klossowki, 2002) that has to be destroyed to reach the essence of the universe and its ontological truth (Castel, 2014, p.110-117): a permanent material process of destruction, which is perfectly described by the pope Braschi in Juliette, or Vice Amply Rewarded (Sade, 1987b, p.166-182). This ethical achievement of the ontological truth in few superior human beings supposes a systematic practice of excess: the true libertine must cross all the degrees of turpitude. The History of Juliette (Sade, 1987a, 1987b) thus expresses the implicit truth of The 120 Days of Sodom. The largest deployment of sexual singularities only makes sense in a journey towards the extreme, which is the only way to reveal a freedom of the will based on the immanent dynamics of nature. Sade's writings are neither a clinical or empirical based catalogue of sexual variations, nor he is a precursor of the psychopathology of sexuality in any way, because the nexus of his thinking is the extensive (number) and the intensive (intensity) quantity of criminal pleasure.

Nonetheless, the illusion of Sade as a precursor of sexology is not an isolated representation, but has its own history. It is the result of the 19th century readings of Sade through the filter of psychiatry from the 1850s in France and of the sexology at the turn of the 
20th century in France with Paul Tournier (known as Dr Marciat), and in Germany with the sexologist Iwan Bloch who discovered the manuscript of The 120 days of Sodom and published Sade's works at the beginning of the 20th century. The view I propose in this paper explains this very process that led Sade to become such a figure of sexual perversion.

\section{The first Sadian legend.}

A first legend about Sade was constructed between the Enlightenment and the Monarchie de Juillet in France. Its first origin is the Arcueil affaire in 1768, which was the trigger of the collective interest for Sade and of the construction and the diffusion of his legend in the collective imaginary (Lever, 1991, p. 131; Vilmer, 2005, p. 127; Vigarello, 1998, p.87-90). Sade was arrested and imprisoned after he kidnapped, raped and whipped a widow reduced to begging. This affair was popularized and romanticized by the media in a new social and political context of public denunciation of aristocratic abuses and social injustices. The press quickly transformed the story. Rape and violence became a cruel and bloody game with knifes and scrapers. Sade was compared to Gilles de Rais, who was a cultural figure of great moral monstrosity since the early modern period (Lever 1991, p. 180-181). Rétif de la Bretonne, Sade's great adversary, completed this portrait in his Nuits de Paris in 1788 ("The dissected living woman", Rétif de la Bretonne, 1788, p. 2566-2570). According to Rétif, Sade would have imprisoned Rose Keller, attached her to a dissecting table and attempted to dissect her.

From this moment, Sade became an exemplar figure of cruelty, erotic violence and love for blood. The rest of his tumultuous life, with the diffusion of his scandalous writings, his multiple imprisonments, and his internment in Charenton asylum forged an indissoluble link between this early legend about the man and his work. During the first decades of the 19th century, biographies and dictionaries amplified this paper-and-flesh legend. It is then not surprising that in 1835 in France, the meaning of the word "sadism" referred both to Sade's life and to his novels: sadism was defined as a "dreadful aberration of debauchery" and at the same time as a "monstrous and antisocial system insulting nature" (Boiste and Nodier, 1835, p.642).

In 1849 , this first legend became the main operator in the invention of the modern clinical field of sexual perversion in psychiatry.

\section{Sade and the invention of the modern concept of sexual perversion}


In 1849, a criminal affair shook Paris and the rest of France: the military trial of the necrophile Sergent François Bertrand, called the "vampire of Montparnasse" by the press, who deterred, dismembered and destroyed corpses in Parisian cemeteries while having sex with some of the bodies. Far from a criminal anecdote, this affair was the occasion of an epistemological turn (Foucault, 1999; Davidson, 2001; Mazaleigue-Labaste, 2014, p.127163). It raised a psychopathological debate that led to the construction of the modern concept of sexual perversion, to the definition of some of its species (exhibitionism, fetishism, sadism, etc.), and therefore to the opening of the field of the first sexology.

The problem posed by Bertrand's case was bound to the French legal context of the midnineteenth century that defined an exclusive relation between penal responsibility and madness through Article 64 of the Penal Code. In theory, either Bertrand was mentally sane and only vicious, an evildoer responsible for his acts who should be punished (fined and imprisoned), or he was a mad person misbehaving and was irresponsible. But in practice, François Bertrand was very embarrassing for the judicial order. This former seminarian and philosophy student was known as a pleasant man and comrade, a good sergeant and was quite handsome ${ }^{1}$. In other words, he did not show either signs of moral perversity or symptoms of mental illness. It was consequently very hard to determine his penal responsibility and his institutional fate: prison or asylum?

The psychiatric debate focused exactly on this matter. In order to demonstrate that Bertrand was actually mentally ill, some of the French alienists and physicians invented new categories of mental illnesses and more precisely of psychosexual illnesses that were named "perversion of sexual instinct". Claiming that these new kinds of psychopathologies were frequent, although previously not considered as illnesses, permitted them to determine that some irregular sexual conducts and desires were pathological; among them the desire for corpses, named "necrophilia" three years later by the Belgian alienist Joseph Guislain (Guislain, 1852, p.257). Therefore they were able to conclude Bertrand was both mad and irresponsible for his acts (even if the military court condemned him).

Understanding the role of Sade in this epistemological event requires a closer look at these new categories of perversion of the sexual instinct and the corresponding clinical cases, especially those listed by the two psychiatrists Claude-François Michéa (1849) and Alexandre Brierre de Boismont (1849) and the army physician Félix Jacquot (1849). Brierre and Michéa

\footnotetext{
1. The physiognomonic scheme of perception was very strong in the middle of the century; it was scientifically alleged and commonly accepted that mental illnesses and moral qualities and defects appeared on the body and the face of the individual.
} 
thus forged the category of "cruel love" or "bloody love", which is the conceptual basis for sadism as a psychopathological notion. This concept included old cases of violence under a new type of category: the pathologically deviant eroticism, of which violence is only an effect or an expression. This new concept of "sadism" as a psychosexual disorder was actually based on the sadian legend: it was its psychiatric translation. Indeed, Brierre and Michéa forged the category of "cruel love" by using the cultural figure of Sade previously constructed as a model and as a paradigmatic case.

But the role played by the "sadian legend" in psychiatry goes beyond the invention of sadism as a psychosexual disorder. Indeed, the other species of sexual perversion forged in 1849 seems very heterogeneous, and the common features they share cannot be apprehended without taking into account the cultural representation of Sade. In addition to "cruel love", the list of perversions included pederasty as mental disorder (and not as a vice) (Jacquot, 1849) and "Greek Love" by Michéa - subdivided in "philopaedie", for men, and "tribadism", for women (1849). This was the first step in the psychiatrisation of same-sex relations, completed in the 1870s with the concept of sexual inversion (it should be noted that Michéa was himself homosexual (Féray, 2015). When he included same-sex relations and desires in the list of sexual perversions, it was not meant to normalize it, but rather to protect men who loved men from social contempt, stigmatisation and judicial repression - of which Michéa was also a victim). Then came bestiality as a mental disorder ${ }^{2}$ (Michéa, 1849; Brierre, 1849; Jacquot, 1849) that is the conceptual matrix of zoophilia, a first sketch of voyeurism and three sketches of fetishism (the case of a musician who could only pleasure in masturbating while standing in a Church facing a velvet dress, by Brierre, the attraction for inanimate objects by Michéa, and a psychological distinction introduced by Jacquot ${ }^{3}$, which became cardinal in Alfred Binet's theory of fetishism (Binet, 1888). The grouping of the clinical cases of sexual perversion is also very strange at first sight. Michéa compared thus Bertrand, Gilles de Rais and "the insane book written by the Marquis of Sade" (it could be Juliette or Justine), and Brierre compared Héliogabale, Pasiphaë, the velvet dresses lover, the mad criminals, a man who loved to put leeches on women's body, and Sade (as a man, not a writer). How could psychiatrists and physicians claim these heterogeneous and disparate cases were all different species of the same kind of disorder? They actually assessed each of them have similarities with the others and constructed a group based on these likenesses (Michéa, 1849, p.339;

\footnotetext{
${ }^{2}$ And not as moral perversity as it was previously considered.

${ }^{3}$ The gap between an occasional desire for beautiful and freshly dead women, which belongs to the normal love psychology and aims at the "total being, the very person", and the attraction for corpses as corpses, which is a desire for an inert and partial object
} 
Mazaleigue-Labaste, 2014, p.137-150), which means that this group of psychosexual disorders belongs to a family resemblance structure model (Kleiber, 1990). Each of the family members shares a resemblance with another, but all of them do not have to share the same characteristics, just as the different activities we call "games" do not all share the same features (chess is neither paintball nor hopscotch) (Wittgenstein, 1953). This implicit principle guiding the grouping of heterogeneous cases in the family of sexual perversions reveals the role of the representation of Sade in the opening of the first sexological field. Indeed, for an educated man of the early $19^{\text {th }}$ century, bestiality resembled to sodomy - bestiality being even often considered as "sodomy" in its broad definition -, as they belonged to the universe of the illicit erotic acts of the Ancien Régime. But these acts also resembled the written crimes of Sade, the great eulogist of illicit and sodomistic love. And the legendary Sade as described by Rétif desired blood like the man who put leeches on women and Gilles de Rais. The crimes of the latter resembled those of the mad criminals, which resembled the atrocious acts perpetrated by Bertrand on dead bodies. And the velvet lovers, the leeches lovers, the child rapist Gilles de Rais and the debauchees whipping prostitutes (as Sade) shared strange erotic preferences they could all satisfy in special urban brothels that offered these specialities since the $18^{\text {th }}$ century (Muchembled, 2005, p.166-167), as well as the men who loved receiving farts (quoted by Jacquot) like Dolmancé in The philosophy in the Boudoir (Sade, 1976) who was also a killer.

These family resemblances obviously depend on a set of cultural and moral representations. And one can measure their dependence to the Sadian legend diffused in the former decades. Close attention should be paid to the double reference introduced by the psychiatrists to Sade's romanticised life as a prototype of the aristocratic depravation, and to his work as a masterpiece of debauchery. Long before the French alienists, Sade had constructed a coherent range of erotic singularities, from the most harmless to the most atrocious, referred to the crime as a metaphysical value. His writings were well diffused and known by educated men of the first half of the $19^{\text {th }}$ century thanks to underground editions. As Jules Janin said in 1834, Sade "is everywhere, he is in every bookcase, on a mysterious shelf one always discovers" (Janin, 1834, p.48). And the diffusion of the representation and of the work of Sade shows the existence of an erotic imaginary of the opened body. Both legendary Sade and writer Donatien explored the body and its orifices through pain. It should be remembered that Sade was fascinated by the "anatomical Venus" (anatomical waxes representing opened bodies) at the Specola in Florence (Didi-Huberman, 1999). Sade's interest manifests in the way his characters dilate holes and even create new ones, such as 
Cardoville who inserts a heated metal ball in Justine's anus (Sade, 1995) and the libertines in The 120 days of Sodom who apply the rat torture to their young victims (a rat forced to enter in the body by tearing apart the rectum) (Sade, 1998). Moreover, the Sadian body is not desired in its whole and as a subject of desire, but only as an object considered as a juxtaposition of dismembered parts (Barthes, 1971). Behind clinical cases and new species of psychosexual disorders invented in 1849, we can discern this Sadian pattern: violence, cruelty and love for blood that give sexual pleasure. Therefore it is not by chance that the modern conception of sexual perversion emerged at the occasion of the François Bertrand affair, namely a violent destruction of corpses and an exploration of the internal organs that provides pleasure. Bertrand was not only a necrophile, but a destructor, a dismemberer, a ripper, who opened women's bodies, tore them apart and played with their entrails. It explains why Richard von Krafft-Ebing and the French criminologist Alexis Épaulard considered him as an extreme case of sadism (Krafft-Ebing, 1893/1895, p.89; Épaulard, 1901). Sade actually belongs to the history of sexuality and sexology, not as a precursor, but rather because of the cultural diffusion of his legend and his texts. One can thus say sexual perversion, this psychopathological invention, is Sadian and bound to erotic cruelty.

In summary, the cultural function Sade acquired through the diffusion of his legend, inherited from the Enlightenment and from his work, explains why French psychiatrists perceived resemblances between apparently disparate cases of erotic acts and desires. Psychiatry built the modern concept of sexual perversion and its clinical field on collective representations bound to Sade's figure. The Sadian legend was thus a major factor in the invention of the sexological field in the Western world. Therefore the pathologization of homosexuality cannot be considered as the heart of the history of "abnormal" sexuality in the 19th century. Its first nexus was erotic violence and cruelty, namely sadism. That's why atrocious rapists and killers belong since 1849 to our representations of perversion, from Gilles de Rais and Sade to our contemporary serial killers.

But psychiatrists also created a new representation of Sade by pushing back the limits of the psychopathological field. They pathologized Sade and made him a paradigmatic case of psychosexual disorder, just as they did for Gilles de Rais. From 1849 onward, Sade, Rais, and the other figures of aristocratic debauchees became typical cases of sadism for the psychology of sexuality and sexology (Moreau, 1887, p.65; Roudinesco, 2007), and the pathological status of Sade was fixed until the late 19th century. Before 1849, he oscillated between madness and crime because of his years at the Charenton asylum and of the outrageousness of his work and life. In the first decade of the 19th century, the head doctor of Charenton, 
Antoine Royer-Collard, claimed Sade was not mentally ill in any way, but only a horrible vicious man. Even in 1849, some of the psychiatrists involved in the debate about Bertrand refused to consider Sade as a pathological case (Lunier, 1849). However, after Michéa and Brierre de Boismont, Sade was included in the domain of mental disorder and passed from a legend of moral perversity to a representation of sexual perversion. Since this time his figure has troubled European psychiatry and psychoanalysis.

The psychopathological representation of Sade is a first dimension of Sade's contemporary legend, but there is another one: Sade as a precursor both of sexual liberation and of sexology.

\section{(3) The de-pathologization of Sade and the emergence of a third legend}

At the turn of the century, two types of scientific discourses about sexuality transformed the representation of Sade: French criminology and German sexology (sexology as a definite and institutionalized field of science).

In 1899, Alexandre Lacassagne, founder and head of the French school of Criminal Anthropology in Lyon, published a collective book about a criminal case that made headlines between 1897 and 1899 (Lacassagne (ed.), 1899): The Vacher Affair. Vacher, named "Vacher the Ripper" by the press in reference to Jack, is considered as the first known serial killer in France (Vigarello, 1998). He murdered, raped and mutilated at least eleven young shepherds and shepherdesses over several years. He was arrested in 1897 and then judged and guillotined in 1898. Lacassagne was one of the forensic experts on the case alongside two other members of his school. They diagnosed him as a sadist. But despite Vacher's symptoms of mental disorders and possibly of neurological problems, the experts did not consider him mentally ill and consequently assessed he was entirely responsible for his acts. The criminologists thus invented a new kind of sadism: sadism that is not a mental disorder. This thesis is one of the key points of the collective book published in 1899, Vacher and the sadistic crimes. In one of the papers, Lacassagne compared Vacher to Gilles de Rais and claimed his sadism made him entirely responsible.

The counterpart of this repressive conception of sadism was the rehabilitation of Sade in another paper entitled The Marquis of Sade and the sadism by Dr Marciat (1899) (pseudonym of Dr Paul Tournier) (Azar, 1975/2014, p. 36; Levent, 2004). Through a well-documented biography of Sade, Marciat tried to deconstruct the two dimensions of the sadian legend, the crimes of the man and the work of the writer. Only the latter could justify the label "sadism" 
and certainly not the acts of the man, who was not ill nor vicious, but actually a victim of the socio-political context of the Directoire and of the First Empire. In his demonstration, Marciat showed how Sade's adversaries made up the legend and paid homage to Sade's political philosophy. Therefore he de-pathologized the figure of Sade, took him out of the psychopathological field and introduced a distinction between two forms of sadism. The first one is the "little sadism", which is most closely related to Sade: a combination of erotic acts and cruelty with an anarchist philosophy of sexual liberty. The second one is the "great sadism", a psychological characteristic that leads the individual to monstrous crimes. Consequently, Marciat deconstructed the group of the "blood lovers" constructed by psychiatry in 1849 . Then, for Marciat, psychiatrists made a mistake by comparing Sade to Gilles de Rais, because they are qualitatively and essentially different.

In a paper following Marciat's, Lacassagne adopted this distinction and gave it a psychophysiological and sexological reference. While the little sadism is essentially driven by ideas and fantasies, the great one is rooted in neurological and cerebral processes leading necessarily to criminal acts (Lacassagne, 1899, p.243). The "little sadist" (Sade) is not dangerous for society, while the great one (Vacher, Gilles de Rais) is.

The consequences of this new view of sadism for the contemporary representations and conceptions of sexuality were crucial. The distinction between two kinds of sexual abnormalities allowed positioning the first one as harmless and socially meaningless. Indeed, little sadists were freed from the shadow of the great bloody monster. Therefore the isolation of "great sadism" granted the possibility of seeing numerous abnormal sexualities not as illnesses and risk factors of criminality, but as gentle varieties of the human sexual behaviour sexologists could observe with a liberal attitude and without any moral judgment. The rehabilitation of Sade was one of the conditions of a sexology stricto sensu. It explains why, despite his very strong and repressive conception of criminal justice and social defence, Lacassagne published in his journal (Archives de l'Anthropologie Criminelle) the studies about homosexuality of the French homosexual militant and sexologist Marc-André Raffalovich and why he integrated a cultural study on Sade in a criminology book about Vacher.

But Marciat went further in his paper. He analysed Sade's supposed theories of sexual sense. This is a retrospective projection of the psycho-sexological concepts and theories of the last decades of the nineteenth century on Sade's work (the notion of "sexual sense" appeared frequently in the sexological field between 1870 and 1910). Several years later, the great sexologist and editor of Sade, Iwan Bloch, proposed a similar interpretation on Sade's work 
and life, which was quickly diffused. In 1901, Bloch published a book under the pseudonym Eugen Duehren (1901) in which he develops a biography of Sade, an interpretation of his novels and of his philosophy, and an analysis of the sexological knowledge found in Sade's work. Between Marciat and Bloch, an illusion thus emerged: Sade as the precursor of psychopathology of sexuality and sexology. One can now fully understand why Maurice Heine was convinced Sade was a great clinician of sexuality.

\section{Conclusion}

Retracing the history of the Sadian legend and its appropriation by the early Scientia Sexualis in France provides a new view on the history of sexual psychology, and therefore allows reconsidering some assumptions about the history of sexuality as well as its historiography. Indeed, the cultural figure of Sade was a crucial factor in the opening of the first sexological field in the mid- $19^{\text {th }}$ century France, before homosexuality focused the attention in the 1860s Germanic area. It means gender identity and sexual orientation were neither the origin nor the nexus of Scientia Sexualis in its whole, and explains the increasing importance of Sade and sadism in the field of sexual sciences until the $20^{\text {th }}$ century. Eventually, in the context of a rediscovery of Sade at the turn of the $20^{\text {th }}$ century, Marciat and Bloch contributed to build a new Sadian legend with multiple dimensions: Sade as a revolutionary and victim of political powers, Sade as a eulogist of sexual liberation and Sade as a precursor and pioneer of sexological knowledge. Through the different editions of Sade's texts and their diffusion, their analyses by Maurice Heine from 1926 and the surrealists' interpretations of Sade, this figure went through the $20^{\text {th }}$ century until today - with Annie Le Brun.

Azar A. (1975) Le sadisme et le masochisme innominés. Étude historique et épistémologique de la brèche de 1890. Thèse de troisième cycle pour le doctorat de psychologie et de psychopathologie. Paris: Université de Paris VII.

Barthes, R. (1971) Sade, Fourier, Loyola. Paris: Seuil.

Binet, A. (1888) Le fétichisme dans l'amour. In: Binet, A. Études de psychologie expérimentales. Paris: Alcan, pp.1-83.

Boiste, P. C. V. and Nodier C. (1835) Dictionnaire universel de la langue française. Paris, Firmin Didot.

Brierre de Boismont, A. (1849) Remarques médico-légales sur la perversion de l'instinct génésique. Gazette médicale de Paris. 4(3), pp.555-564.

Castel, P.-H. (2014) Pervers, analyse d'un concept, suivi de Sade à Rome. Paris: Éditions d'Ithaque. 
Davidson, A. I. (2001) The Emergence of Sexuality. Historical Epistemology and the Formation of Concepts. Cambridge (Mass.): Harvard University Press.

Didi-Huberman, G. (1999) Ouvrir Vénus: nudité, rêve, cruauté. Paris: Gallimard.

Duehren, E. (1901). Der Marquis de Sade und seine Zeit, ein Beitrag zur Kultur und Sittengeschichte des 18. Jahrhunderts, mit besonderer Beziehung auf die Lehre von der Psychopathia Sexualis. Berlin und Leipzig: H.Barsdorf.

Épaulard, A. (1901) Vampirisme, nécrophilie, nécrosadisme, nécrophagie. Lyon: Storck.

Féray, J.-C. (2015) L'impossible conciliation ou la vie héroïque du Dr Claude-François Michéa. Paris : Quinte-Feuilles.

Foucault, M. (1976) Histoire de la sexualité I. La volonté de savoir. Paris: Gallimard.

Foucault, M. (1999) Les anormaux. Cours au Collège de France 1974-1975. Paris: SeuilGallimard.

Guislain, J. (1852). Leçons orales sur les phrénopathies ou traité théorique et pratique des maladies mentales. Volume 1. Gand: Hebbelynck.

Heine, M. (2010) Recueil de confessions et observations psycho-sexuelles tirées de la littérature. Paris: La Musardine.

Jacquot, F. (1849). Feuilleton. Des aberrations de l'appétit génésique. Gazette médicale de Paris: journal de médecine et des sciences accessories. 4(3), pp.575-578.

Janin, J. (1834) Le marquis de Sade. La Revue de Paris. 12, pp.32-70.

Kleiber, G. (1990) La sémantique du prototype. Catégories et sens lexical. Paris: Puf.

Klossowski, P. (2002) Sade mon prochain. Précédé de Le Philosophe scélérat. Paris: Seuil.

Krafft-Ebing (von), R. (1895), Psychopathia Sexualis, avec des recherches spéciales sur l'inversion sexuelle. Translated by Laurent and Csapo, Paris: Carré

Lacassagne, A. (1899) Le sadisme au point de vue de la médecine légale. In: Lacassagne, A. (ed.) Vacher l'éventreur et les crimes sadiques. Lyon: Storck, pp.239-243.

Lacassagne, A. (ed.) (1899) Vacher l'éventreur et les crimes sadiques. Lyon: Storck.

Levent, J-M. (2004) Sade, l'homme naturel du XIXe siècle. Lignes. 14, pp.167-191.

Lever, M. (1991) Donatien Alphonse François, marquis de Sade. Paris: Fayard.

Lunier, L. (1849) Examen médico-légal d'un cas de monomanie instinctive. Affaire du sergent Bertrand. Annales médico-psychologiques. 1(2), pp. 351-379.

Marciat, Dr. (1899) Le marquis de Sade et le sadisme. In: Lacassagne, A. (ed.) Vacher l'éventreur et les crimes sadiques. Lyon: Storck, pp.185-237.

Mazaleigue-Labaste, J. (2014) Les déséquilibres de l'amour. La genèse du concept de perversion sexuelle de la Révolution française à Freud. Paris: Éditions d'Ithaque.

Michéa, C.-F. (1849) Des déviations maladives de l'appétit vénérien. L'Union médicale. 85(3), pp.338-339.

Moreau, Paul (1887) Des aberrations du sens génésique. $4^{\text {th }}$ edition. Paris: Asselin et Houzeau.

Muchembled, R. (2005) L'orgasme et l'Occident. Paris: Seuil.

Rétif de la Bretonne, E.D. (1788) Les nuits de Paris ou le spectateur nocturne. Volume 11. London: s.n.

Roudinesco E. (2007) La part obscure de nous-mêmes: une histoire des pervers. Paris: Albin Michel.

Sade (de), D.A.F. (1976) La philosophie dans le boudoir. Paris: Gallimard.

Sade, D.A.F. (1987a) Histoire de Juliette ou les Prospérités du Vice. Volume 1. Paris: Pauvert.

Sade, D.A.F. (1987b) Histoire de Juliette ou les Prospérités du Vice. Volume 2. Paris: Pauvert.

Sade, D.A.F. (1995) Justine, ou les Malheurs de la vertu. Paris: Livre de Poche.

Sade, D.A.F. (1998) Les 120 journées de Sodome. Paris: 10/18. 
Vigarello, G. (1998) Histoire du viol, XVIe-XIXe siècle. Paris: Seuil

Vilmer, J.-B. J. (2005) Sade moraliste. Le Dévoilement de la pensée sadienne à la lumière de la réforme pénale au XVIIIe siècle. Genève: Droz.

Wittgenstein, L. (1953). Philosophical investigations. Oxford: Basil Blackwell. 